Oral Tradition, 18/2 (2003): 214-215

\title{
How the Beowulf Poet Composed His Poem
}

\author{
Robert Payson Creed
}

Received wisdom has it that the Beowulf poet put together his poem halfline by halfline ("verse" by "verse"). My work on the poem over the past fifty years has led me to think that we can begin to understand how the poet composed his tale, clause by clause, only if we turn our attention to the whole lines in which he told the story.

The poet built each four-measure-line - and each of the rare five- and six-measure lines-around the alliteration of the root syllables of stressed words. His tradition seems to have provided him with many alliterating word pairs that encapsulate culturally significant ideas. For example, the poet built five lines around the pair dom (achievement) and deað (death)_dom before death, at least seven lines around the pair eorl (nobleman) and ellen (brave action), and nine around the pair sop (truth) and secgan (say). This does not mean, however, that the poet was constrained to frame each clause within the confines of a single alliteration: rather, he composed many passages with suppleness and flexibility simply by beginning a new clause in the middle of the line. This expedient left him free to develop the clause around different alliterations.

The rhythm of the poem is based on the stress patterns of the poet's language; most Old English words, like ellen or secgan, begin with a heavier stress and end with a lighter stress. This pattern translates to a downbeat followed by an upbeat, the simplest kind of rhythm. Each measure of the poem repeats this rhythm. Yet there is no question of monotony: though all measures are identical in rhythm and theoretically identical in the length of time it takes to speak them, successive measures are likely to contain very different combinations of stressed and unstressed syllables-and even precisely timed rests. Thus there is a great variety created both by the material that fills each measure and by the succession of different types of measures. The material within the measures makes possible only seven different types of measure. But the various combinations of stressed and unstressed syllables, along with measure-initial and measure-final rests, produce about fifty different subtypes. The rich variety of these subtypes is the source of the complexity of the poet's prosody. 
What was, perhaps, of greatest use to the poet as he composed was the knowledge that many, though not all, of the subtypes manifest themselves as single words, compounds, and even short (measure-length) phrases. These words and phrases were the ready-made-and readily made-building blocks of the poet's composition. So the poet did not have to rely on his ability to recall halfline or whole-line formulas-or even the few formulas that wrap around two lines. He had in mind what he needed: a prosody shaped by his lexicon, with which he could tell his story not only rapidly and with flexibility but even at times — often in this poem! — with virtuosity.

University of Massachusetts, Amherst

\section{References}

Creed 1959

Robert Payson Creed. "The Making of an Anglo-Saxon Poem.” English Literary History, 26:445-54.

Creed 1990 Reconstructing the Rhythm of Beowulf. Columbia: University of Missouri Press. 